\title{
EFEK PEMBERIAN BISKUIT ULVATERHADAP PENURUNAN KADAR GLUKOSA DARAH TIKUS YANG DIINDUKSI SUKROSA
}

\section{The Effect of Ulva Biscuit Diet on Reducing Blood Glucose Levels of Sucrose Induced Rats}

\author{
Ellya Sinurat', Dina Fransiska, Sihono, dan Rinta Kusumawati \\ Balai Besar Riset Pengolahan Produk dan Bioteknologi Kelautan dan Perikanan \\ Jl. KS Tubun, Petamburan VI, Jakarta Pusat, 10260, Indonesia \\ * Korespondensi penulis: ellya_sinurat@yahoo.com
}

Diterima: 1 Juni 2020; Direvisi: 29 Juli 2020; Disetujui: 11 Juni 2021

\begin{abstract}
ABSTRAK
Rumput laut Ulva sp. memiliki kandungan serat pangan tinggi yang diketahui memiliki aktivitas hipoglikemik. Penelitian ini telah melakukan penambahan Ulva sp. pada biskuit sebagai makanan sehat yang kaya serat pangan. Tujuan penelitian untuk mengetahui pengaruh pemberian biskuit Ulva terhadap penurunan kadar glukosa darah pada tikus jantan yang diinduksi sukrosa jenuh. Selain itu, diamati profil hematologi dan biokimia klinis darah sebelum dan setelah pemberian biskuit Ulva. Uji antidiabetes dilakukan menggunakan uji toleransi glukosa oral terhadap tikus jantan yang diinduksi sukrosa jenuh. Biskuit Ulva yang diberikan $1 \mathrm{~g} / \mathrm{kg}$ berat badan (BB) tikus dengan perlakuan kontrol negatif (pakan tanpa biskuit), biskuit tanpa Ulva sp., dan biskuit Ulva setara dengan Ulva sp. 1,5, dan $10 \mathrm{mg} / \mathrm{kg}$ BB. Perlakuan dosis diberikan pada 5 ekor tikus percobaan sekali sehari selama 14 hari. Pengamatan terhadap intoleransi glukosa dilakukan melalui pengukuran glukosa darah setelah pemberian sukrosa jenuh ke semua perlakuan pada hari ke14, dan diukur pada menit ke-0, 30, 60, dan 120. Penimbangan tikus dilakukan pada hari ke-0, 7, dan 14, sedangkan analisis hematologi dan biokimia klinis darah dilakukan pada hari ke-0 dan ke14. Pemberian biskuit Ulva berpengaruh signifikan terhadap kadar glukosa darah, serta menurunkan hematokrit dan hemoglobin darah tikus. Biskuit dengan dosis Ulva setara $1 \mathrm{mg} / \mathrm{kg} \mathrm{BB}$ mampu menurunkan kadar glukosa darah tikus secara efektif pada menit ke-60. Tidak ada perbedaan kenaikan berat badan tikus jantan antara kelompok kontrol negatif dan biskuit Ulva pada hari ke-0, 7, dan 14. Pemberian biskuit Ulva sampai dengan $10 \mathrm{mg} / \mathrm{kg}$ BB tidak mempengaruhi SGOT, SGPT, ureum, dan kreatinin tikus.
\end{abstract}

KATA KUNCI : Ulva sp., glukosa darah, hematologi, intoleransi glukosa

\section{ABSTRACT}

Seaweed Ulva sp. contains high dietary fiber which is known to have hypoglycemic activity. In this study, the addition of Ulva sp. in biscuit products for a healthy food that rich in dietary fiber. The objective of this study was to determine the effect of Ulva added biscuits on blood glucose levels reduction in male rats induced by saturated sucrose. In addition, clinical hematology and blood biochemical profiles before and after the administration of Ulva biscuits were also observed. Antidiabetic method used the oral glucose intolerance test method on male rats induced by saturated sucrose. Ulva biscuits were given at $1 \mathrm{~g} / \mathrm{kg}$ body weight of rats for each treatment. This test used five treatments, namely negative control (rats feeding without biscuits), rat feeding without Ulva added biscuits; and rat feeding with Ulva biscuits equivalent to 1, 5, and $10 \mathrm{mg}$ Ulva sp. $/ \mathrm{kg}$ BW. Each dose treatment was given to five experimental rats once a day for 14 days. Observations on glucose intolerance included measurement of blood glucose levels by giving saturated sucrose to all treatments and measured at 0, 30, 60, and 120 minutes after administration of saturated sucrose. The weighing was carried out on day 0,7 , and 14, while clinical hematological and blood biochemical analyzes were performed on day 0 and 14. The administration of Ulva biscuits had a significant effect on the blood glucose levels of male rats, lowering hematocrit and hemoglobin in rat blood. The concentration of $0.1 \%$ Ulva biscuits in biscuits (equivalent to a dose of Ulva sp. $1 \mathrm{mg} / \mathrm{kg} \mathrm{BW}$ ) was able to effectively reduce the blood glucose levels of rats after 60 minutes. There was no difference in weight gain of male rats between the negative control group and Ulva biscuits on days 0, 7, and 14. The diet of Ulva biscuits with $10 \mathrm{mg} / \mathrm{kg} \mathrm{BW}$ Ulva sp. did not affect the SGOT, SGPT, urea, and creatinine of rats.

KEYWORDS: Ulva sp., blood glucose, hematological, glucose intolerance 


\section{PENDAHULUAN}

Diabetes mellitus (DM) merupakan ketidaknormalan sistem metabolisme karbohidrat, protein, dan lipid secara luas yang disebabkan oleh kekurangan insulin baik secara relatif maupun absolut, sehingga menyebabkan gangguan kesehatan tubuh. Penyakit DM merupakan penyakit kronis yang ditandai dengan polidipsia, polyphagia, poliurea, dan disertai dengan penurunan berat badan, meskipun nafsu makan bertambah dengan ditandai kadar glukosa darah di atas normal (Yusrani, Darmayanti, \& Yusa, 2015). Selain faktor genetik, penyakit DM dapat disebabkan oleh pola makan yang tidak seimbang, konsumsi makanan tinggi kalori, tinggi lemak, dan rendah serat (Tama, Dewi, \& Ibrahim, 2012).

Salah satu cara untuk menurunkan kadar glukosa darah adalah melalui diet dengan bahan pangan yang bersifat hipoglikemik. Sifat hipoglikemikbahan pangan sangat ditentukan oleh komponen-komponen yang terdapat dalam bahan pangan tersebut, salah satunya adalah kandungan serat pangan. Mekanisme efek hipoglikemik pada serat pangan adalah kemampuannya menurunkan efisiensi penyerapan karbohidrat. Kondisi ini akan mengurangi dan memperlambat penyerapan glukosa dalam darah, menurunkan respon insulin, meringankan kerja pankreas sehingga dapat memperbaiki fungsinya dalam menghasilkan insulin, serta mengurangi pemakaian glukosa oleh hati (Arif, Budiyanto, \& Hoerudin, 2013; Kusharto, 2007).

Rumput laut merupakan salah satu bahan pangan yang mengandung serat dan dapat digunakan dalam terapi diet penderita DM tipe 2. Ulva lactuca kaya akan serat pangan larut air $(20,53 \%)$ dan serat pangan tak larut sebesar 34,37\% (Yaich et al., 2015), sedangkan serat pangan total Ulva rigida mencapai 43\% (Thunyawanichnondh et al., 2020). Kandungan polisakarida dalam dinding sel rumput laut $U$. lactuca cukup tinggi yaitu $54 \%$ dari berat kering (Yaich et al., 2015). Rumput laut hijau, terutama U. lactuca merupakan sumber aldobiuronans atau ulvan yang memiliki gugus monosakarida utama $\alpha$-L-rhamnosa (Robic, Gaillard, Sassi, Leral, \& Lahaye, 2009). Ulvan tersusun atas asam glukuronat, asam iduronat, dan xilosa yang berikatan dengan rhamnosa sulfat yang dihubungkan dengan ikatan glikosidik dan memiliki berat molekul rata-rata $189-8200$ kDa (Alves, Sousa, \& Reis, 2013).

Ulvan memiliki aktivitas biologis dan fisiologis, antara lain sebagai antihiperlipidemia, antikoagulan, immunomodulator, antiviral, antitumor, dan antioksidan (Pereira, Mulloy, \& Pereira, Mulloy, \& Mourão, 1999). American Diabetes Association merekomendasikan penderita diabetes mengkonsumsi total serat pangan larut maupun tidak larut 20-35 g/hari (ADA, 2004). Pengujian secara in vivo menunjukkan ekstrak Ulva sp. berpengaruh terhadap kontrol glikemik dan efektif menurunkan kandungan lipid dalam darah (Mohapatra, Bhattamishra, Panigrahy, \& Parida, 2016).

Ulvasp. dalam bentuk tepung dapat difortifikasikan pada biskuit, salah satu produk pangan yang banyak dikenal masyarakat dengan tingkat konsumsi yang luas, dan memiliki masa simpan relatif lama. Tujuan penelitian ini untuk mengetahui pengaruh pemberian biskuit Ulva terhadap penurunan kadar glukosa darah pada tikus jantan yang diinduksi sukrosa jenuh. Selain itu juga dilakukan pengamatan profil hematologi dan biokimia klinis darah sebelum dan setelah pemberian biskuit Ulva.

\section{BAHAN DAN METODE}

\section{Bahan}

Bahan utama yang digunakan dalam penelitian ini adalah rumput laut Ulva sp. yang diperoleh dari perairan pantai Gunung Kidul, Yogyakarta. Jenis tepung untuk pembuatan biskuit Ulva adalah tepung singkong modifikasi (modified cassava flour/mocaf) dengan indeks glikemik rendah. Bahan yang digunakan untuk uji in vivo yaitu sukrosa, aquabidestilata, Kit -Glucose GOD FS- (DiaSys), dan tikus jantan (Rattus norvegicus) galur Sprague dawley.

\section{Metode}

\section{Pembuatan biskuit Ulva}

Pembuatan biskuit menggunakan metode modifikasi Setyowati dan Nisa (2014). Formula biskuit terdiri atas tepung mokaf $15,71 \%$; maizena $6,45 \%$; tapioka $14,52 \%$; tepung Ulva sp. $(0,1 \% ; 0,5 \%$ dan $1,0 \%$ ); margarin $33,87 \%$; butter $14,52 \%$; telur $11,29 \%$; soda kue $0,32 \%$; dan sukralosa $3,23 \%$. Rumput laut Ulva sp. direndam dalam air panas (blanching) selama 1 menit, kemudian dikeringkan dan digiling sampai menjadi tepung dengan ukuran 40 mesh. Tepung Ulva siap diolah menjadi biskuit.

Adonan pada pembuatan biskuit terdiri atas sukralosa, margarin, dan butter. Adonan diaduk sampai homogen, kemudian ditambahkan telur dan soda kue, kemudian diaduk kembali sampai homogen. Adonan kemudian ditambahkan tepung mokaf, maizena, tapioka, dan tepung Ulva sambil diaduk. Adonan yang dihasilkan dibentuk dan dioven pada suhu $160^{\circ} \mathrm{C}$ selama 30 menit. Biskuit yang dihasilkan didinginkan dan dikemas. Analisis proksimat 
dilakukan terhadap biskuit Ulva yang meliputi kadar air (BSN, 2006a), abu (BSN, 2010), lemak (BSN, $2006 \mathrm{~b})$, protein (BSN, 2006c), dan serat pangan (AOAC, 2006).

\section{Uji in vivo biskuit Ulva sebagai antidiabetes (Togubu, Momuat, Paendong, \& Salma, 2013 dengan modifikasi)}

Tikus yang digunakan adalah tikus jantan galur Sprague dawley, umur 6-8 minggu dengan bobot sekitar $160 \mathrm{~g}$ (variasi bobot tidak lebih dari 20\%) dengan spesifikasi sesuai Perka BPOM No. 7 tahun 2014 (BPOM, 2014). Uji in vivo telah mendapat persetujuan etik dari Komisi Etik Hewan Fakultas Kedokteran Hewan, Institut Pertanian Bogor (IPB). Tikus dipelihara selama 14 hari sampai berat $200 \mathrm{~g}$ sambil diaklimatisasikan untuk menyesuaikan hewan coba dengan lingkungan penelitian. Setelah periode aklimatisasi (sebelum diberikan perlakuan), tikus percobaan dipuasakan dari makan selama 14-18 jam dengan masih diberikan air minum.

Sebanyak 2-3 ekor tikus dipelihara dalam tiap kandang berukuran $30 \times 40 \mathrm{~cm}^{2}$ dengan jumlah total tikus 50 ekor untuk 5 perlakuan (masing-masing 10 ekor, termasuk untuk mengantisipasi adanya kematian). Setelah dipuasakan, tikus percobaan ditimbang dan diberikan perlakuan. Pada penelitian ini dilakukan 5 variasi perlakuan seperti pada Tabel 1. Sediaan uji (biskuit Ulva) dilarutkan dengan bahan pembawa yang sesuai, yaitu aquadestilata. Jumlah cairan maksimal larutan biskuit Ulva yang diberikan sebesar $2 \mathrm{~mL} / 200 \mathrm{~g}$ bobot badan setara dengan dosis biskuit $1 \mathrm{~g} / \mathrm{kg}$ BB. Pemberian larutan biskuit dilakukan menggunakan sonde lambung, sekali sehari selama 14 hari. Pengambilan sampel darah dilakukan sebanyak 2 kali, yaitu sebelum dan setelah selesai perlakuan.
Uji antidiabetes dilakukan melalui pengukuran intoleransi glukosa menggunakan metode Uji Toleransi Glukosa Oral (UTGO), dengan parameter: (1) kadar glukosa darah, (2) bobot badan, (3) hematologi, dan (4) biokimia klinis darah. Penimbangan bobot badan dilakukan pada hari ke-0, 7, dan 14. Pada awal dan akhir penelitian, hewan percobaan diambil darahnya untuk analisis hematologi dan biokimia klinis darah. Darah diambil dari vena coccigea dan vena cava inferior sebanyak 3-5 mL. Darah kemudian dimasukkan tabung Ethylene Diamine Tetraacetic Acid (EDTA) untuk analisis hematologi dan diferensiasi darah putih serta tabung plain untuk analisis biokimia klinis darah.

Setelah pemeliharan hewan coba selama 14 hari, semua hewan uji dicekok sukrosa jenuh (konsentrasi $70 \%$ ) sebanyak $2 \mathrm{~mL} /$ ekor untuk meningkatkan kadar glukosa darahnya, kemudian kadar glukosa darahnya diukur pada menit ke-0, 30, 60, dan 120 mengikuti metode Togubu et al. (2013). Masing-masing tikus diukur kadar glukosa darah dengan mengambil darah melalui pembuluh darah vena dibagian ekor. Kadar glukosa darah diukur dengan glukometer GlucoDr dengan mengikuti petunjuk operasional alat.

Pemeriksaan profil hematologi dilakukan terhadap konsentrasi hemoglobin menggunakan Hematology Analyzer Sysmax KX-21®, jumlah eritrosit (Red Blood Cell/RBC), hematokrit, jumlah leukosit (White Blood Cell/WBC), dan diferensial leukosit. Sementara itu, perhitungan tetapan darah yang diamati terdiri atas Mean Corpuscular Volume(MCV), Mean Corpuscular Hemoglobin $(\mathrm{MCH})$, dan Mean Corpuscular Hemoglobin Concentration (MCHC). Pemeriksaan biokimia klinis terdiri atas pengamatan fungsi hati melalui kadar Serum Glutamic Pyruvate Transaminase (SGPT) dan Serum Glutamic Oxaloacetate Transaminase (SGOT), yang diukur menggunakan fotometer portable Microlab 300 LX dan dibaca

Tabel 1. Dosis pemberian biskuit Ulva pada tikus Table 1. Dosage of Ulva biscuits feeding in rats

\begin{tabular}{|c|c|}
\hline Kelompok/Group & Perlakuan/Treatments \\
\hline AN & Kontrol negatif (pakan tanpa biskuit)/Negative control (feed without biscuits) \\
\hline A0 & Biskuit tanpa Ulva sp./Biscuits without Ulva sp. \\
\hline A1 & $\begin{array}{l}\text { Biskuit Ulva } 0.1 \% \text { setara dengan Ulva } 1 \mathrm{mg} / \mathrm{kg} \mathrm{BB} / \text { Ulva biscuits } 0.1 \% \\
\text { equivalent with Ulva } 1 \mathrm{mg} / \mathrm{kg} \text { body weight }\end{array}$ \\
\hline A2 & $\begin{array}{l}\text { Biskuit Ulva } 0.5 \% \text { setara dengan Ulva } 5 \mathrm{mg} / \mathrm{kg} \mathrm{BB} / \text { Ulva biscuits } 0.5 \% \\
\text { equivalent with Ulva } 5 \mathrm{mg} / \mathrm{kg} \text { body weight }\end{array}$ \\
\hline A3 & $\begin{array}{l}\text { Biskuit Ulva } 1 \% \text { setara dengan Ulva } 10 \mathrm{mg} / \mathrm{kg} \mathrm{BB} / \text { Ulva biscuits } 1 \% \\
\text { equivalent with Ulva } 10 \mathrm{mg} / \mathrm{kg} \text { body weight }\end{array}$ \\
\hline
\end{tabular}


serapannya tiap menit (A/menit) selama 150 detik pada panjang gelombang $340 \mathrm{~nm}$ dan temperature $37^{\circ} \mathrm{C}$. Selanjutnya dihitung selisih serapan ( $\Delta \mathrm{A} /$ menit), maupun fungsi ginjal melalui kadar urea dan kreatininnya (Rahayu, Yantih, \& Supomo, 2018). Pengamatan profil hematologi tikus dilakukan sebelum (H0) dan sesudah (H14) pemberian biskuit Ulva.

\section{Analisis statistik}

Analisis proksimat dan serat pangan biskuit Ulva dilakukan dari hasil 3 kali ulangan. Data disajikan sebagai nilai rata-rata \pm standar deviasi. Analisis statistik terhadap bobot badan, kadar glukosa darah, hematologi, dan gambaran biokimia klinis darah tikus dengan variasi konsentrasi Ulva sp. pada biskuit dilakukan menggunakan One-Way ANOVA yang dilanjutkan dengan uji Duncan.

\section{HASIL DAN PEMBAHASAN}

\section{Komposisi Kimia (Proksimat) dan Serat Pangan Biskuit Ulva}

Hasil analisis proksimat (Tabel 2) menunjukkan bahwa komponen utama biskuit Ulva adalah

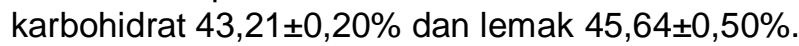
Kandungan serat pangan pada biskuit Ulva juga relatif tinggi, yaitu $47,14 \pm 0,20 \%$, sementara kadar serat pangan biskuit tanpa Ulva adalah $36,94 \pm 0,21 \%$ dari kandungan total karbohidrat. Tingginya kadar serat pangan ini menunjukkan bahwa selain bahan tepung, penambahan tepung Ulva sp. terbukti meningkatkan kadar serat pangan. Kandungan serat pangan yang tinggi menjadikan biskuit Ulva potensial sebagai produk pangan fungsional untuk kesehatan.

Fungsi serat pangan untuk kesehatan tubuh utamanya pada pencegahan kanker usus, menurunkan obesitas, mengontrol kadar gula dan kolesterol dalam darah (Dwiyitno, 2011). Serat larut air menyerap cairan dan membentuk gel selama proses pencernaan. Gel tersebut akan memperlambat pengosongan lambung dan memperlambat penyerapan glukosa sehingga dapat menurunkan kadar gula dalam darah.

\section{Bobot Badan}

Pengaruh pemberian biskuit Ulva terhadap bobot hewan coba dapat dilihat pada Tabel 3. Hasil pengukuran bobot tikus selama 14 hari menunjukkan bahwa pertumbuhan bobot tikus berkisar antara 9-32 g atau 5-20\% per minggu. Pemberian biskuit Ulva dan tanpa biskuit tidak memberikan perbedaan secara signifikan pada pertumbuhan bobot tikus. Levine dan Saltzman (1999) menyatakan bahwa, pertumbuhan tikus normal rata-rata sebesar $1,5-3 \%$ per hari dari bobot awal atau sekitar 7,05-21\% per minggu. Hal ini terjadi apabila nutrisi tercukupi dengan baik dan tikus masih berumur di bawah 5 bulan. Berdasarkan hasil tersebut, maka disimpulkan pertumbuhan tikus percobaan kontrol negatif serta dengan pemberian biskuit tanpa atau dengan Ulva sp. masih normal.

Tabel 2. Hasil analisis proksimat dan serat pangan dari biskuit yang mengandung Ulva $0,1 \%$, tanpa Ulva sp. dan biskuit komersial

Table 2. Result of proximate analysis and dietary fibre of Ulva biscuits $0.1 \%$, without Ulva sp. and commercial biscuit

\begin{tabular}{lccc}
\hline \multicolumn{1}{c}{ Parameter/Parameters } & $\begin{array}{c}\text { Biskuit tanpa Ulva/ } \\
\text { Biscuits without Ulva }\end{array}$ & $\begin{array}{c}\text { Biskuit Ulva/ } \\
\text { Ulva biscuits }\end{array}$ & $\begin{array}{c}\text { Biskuit komersial*/ } \\
\text { commercial biscuit }\end{array}$ \\
\hline Karbohidrat/Carbohydrate (\%) & $44.32 \pm 0.11$ & $43.21 \pm 0.20$ & 65.80 \\
Protein/Protein (\%) & $3.14 \pm 0.00$ & $2.84 \pm 0.00$ & 13.10 \\
Lemak/Lipid (\%) & $46.24 \pm 0.30$ & $45.64 \pm 0.50$ & 8.41 \\
Kadar Air/Moisture content (\%) & $3.45 \pm 0.02$ & $3.74 \pm 0.10$ & 10.10 \\
Kadar Abu/Ash content (\%) & $1.45 \pm 0.03$ & $1.67 \pm 0.00$ & 2.58 \\
Serat pangan/Dietary fiber $(\%)^{\star *}$ & $36.94 \pm 0.21$ & $47.14 \pm 0.20$ & 0.84 \\
\hline
\end{tabular}

Keterangan/Note:

* Contoh biskuit komersial untuk orang diabetes, data disalin dari label kemasan produk/Example of commercial biscuit for diabetic, data were copied from the packaging label.

** Kadar serat pangan dari kandungan total karbohidrat/Dietary fibre content of total carbohydrate 
Tabel 3. Hasil pengukuran bobot badan tikus yang diberi biskuit Ulva

Table 3. Rat body weight measurement result after Ulva biscuits feeding

\begin{tabular}{cccc}
\hline Kelompok perlakuan/ & \multicolumn{3}{c}{ Bobot badan/Body weight $(\mathbf{g})$} \\
\cline { 2 - 4 } Treatments group & Hari ke-0/Day-0 & Hari ke-7/Day-7 & Hari ke-14/Day-14 \\
\hline AN & $160.10 \pm 17.05^{\mathrm{a}}$ & $188.50 \pm 21.58^{\mathrm{a}}$ & $192.80 \pm 31.20^{\mathrm{a}}$ \\
A0 & $166.20 \pm 15.98^{\mathrm{a}}$ & $189.30 \pm 25.94^{\mathrm{a}}$ & $198.00 \pm 24.71^{\mathrm{a}}$ \\
A1 & $162.70 \pm 11.66^{\mathrm{a}}$ & $180.20 \pm 17.41^{\mathrm{a}}$ & $190.10 \pm 24.06^{\mathrm{a}}$ \\
A2 & $179.40 \pm 13.13^{\mathrm{a}}$ & $188.70 \pm 21.48^{\mathrm{a}}$ & $206.10 \pm 25.36^{\mathrm{a}}$ \\
A3 & $162.10 \pm 10.81^{\mathrm{a}}$ & $179.60 \pm 17.77^{\mathrm{a}}$ & $190.40 \pm 15.31^{\mathrm{a}}$ \\
\hline
\end{tabular}

Keterangan/Note:

AN: Kontrol negatif (pakan tanpa biskuit)/Negative control (feed without biscuits)

A0: Biskuit tanpa Ulva sp./Biscuits without Ulva sp.

A1: Biskuit Ulva setara dengan Ulva $1 \mathrm{mg} / \mathrm{kg} \mathrm{BB} /$ Ulva biscuits equivalent to $1 \mathrm{mg} / \mathrm{kg}$ body weight

A2: Biskuit Ulva setara dengan Ulva $5 \mathrm{mg} / \mathrm{kg} \mathrm{BB} / \mathrm{Ulv}$ a biscuits equivalent to $5 \mathrm{mg} / \mathrm{kg}$ body weight

A3: Biskuit Ulva setara dengan Ulva $10 \mathrm{mg} / \mathrm{kg} \mathrm{BB} / \mathrm{Ulva}$ biscuits equivalent to $10 \mathrm{mg} / \mathrm{kg}$ body weight

Huruf superskrip yang berbeda pada kolom yang sama menunjukkan hasil yang berbeda nyata pada $p<0.05 /$

The different superscript letter in the same column indicates significantly different $(p<0.05)$

\section{Kadar Glukosa Darah}

Penentuan kadar glukosa darah pada penelitian ini menggunakan metode UTGO. Uji toleransi glukosa oral adalah pengujian terhadap kemampuan penurunan kadar glukosa darah secara in vivo dengan cara pembebanan glukosa secara oral (Rokhmah, Handayani, \& Al-Rasyid, 2015). Nilai glukosa darah mudah diperoleh karena glukosa mudah dimetabolisme tubuh. Pada penelitian ini tikus diberi sukrosa jenuh untuk meningkatkan kadar glukosa darah dengan cepat (hiperglikemik) tanpa merusak pankreas. Menurut Togubu et al. (2013), setelah pemberian sukrosa jenuh, terjadi peningkatan glukosa darah tikus (hiperglikemia) karena hidrolisis sukrosa oleh enzim sukrase menghasilkan glukosa dan fruktosa yang terjadi di dalam usus halus. Glukosa selanjutnya masuk ke peredaran darah sehingga terjadi peningkatan glukosa darah. Kadar glukosa dapat diturunkan dengan pemberian antihiperglikemik. Pada penelitian ini biskuit Ulva dipelajari aktivitasnya dalam menurunkan kadar glukosa darah.

Hasil penelitian menunjukkan kadar glukosa darah keempat kelompok tikus berkisar antara 90,40-148,30 $\mathrm{mg} / \mathrm{dL}$. Kadar glukosa darah normal pada tikus adalah $72-110 \mathrm{mg} / \mathrm{dL}$ (Tara \& Soetrisno, 2002). Hiperglikemia (peningkatan kadar glukosa darah melebihi kadar normal) terjadi karena penyerapan glukosa yang dikonsumsi berlebih sehingga masuk ke dalam darah. Konsumsi glukosa berlebih menyebabkan sel $\beta$ tidak dapat bekerja optimal menghasilkan hormon insulin sebagai respon dari tingginya kadar glukosa darah (Kondoy, Wullur, \& Bodhi, 2013; Ganong, 1999). Pada jam ke-0 kadar glukosa darah pada perlakuan biskuit tanpa Ulva sudah melebihi kadar glukosa normal $(148,30 \mathrm{mg} / \mathrm{dL})$. Hal ini terjadi kemungkinan karena terdapat komponen dalam biskuit tanpa Ulva yang dapat meningkatkan kadar glukosa darah tikus. Komponen tersebut kemungkinan karbohidrat yang monomer penyusunnya glukosa, sehingga sangat mudah dimetabolisme enzim dalam tubuh. Biskuit yang mengandung tepung Ulva lebih sulit dimetabolisme enzim dalam tubuh, karena kandungan seratnya tinggi dan penyusun utamanya bukan glukosa, melainkan rhamnosa (Kidgell, Magnusson, Nys, \& Glasson, 2019). Pada perlakuan biskuit Ulva, terlihat semakin tinggi kadar Ulva maka kadar glukosa darah semakin rendah namun masih tetap pada batas normal.

Pada menit ke-30, kadar glukosa tikus dengan perlakuan biskuit Ulva berbeda nyata namun masih dalam batas normal, sedangkan pada perlakuan biskuit tanpa Ulva (A0), kadar glukosa darahnya di atas normal. Hasil pengukuran kadar glukosa darah tikus pada menit ke-60, tikus yang diberi pakan normal dan biskuit tanpa Ulva berada di atas normal, sementara perlakuan biskuit Ulva dari semua dosis Ulva berada dalam batas normal dan tidak berbeda nyata. Hal ini diduga kandungan serat pangan pada biskuit Ulva mampu mempertahankan kadar glukosa darah tikus pada batas normal. Dengan demikian pemberian biskuit dengan kandungan Ulva terendah (1 mg/kg BB) telah mampu menurunkan kadar glukosa darah tikus.

Kadar glukosa darah tikus pada menit ke-120 masih mengalami penurunan untuk semua perlakuan 
Tabel 4. Kadar glukosa darah tikus yang diberi biskuit Ulva setelah hari ke-14 Table 4. Blood glucose levels of rats after 14 days Ulva biscuit feeding

\begin{tabular}{crrrrr}
\hline Waktu (menit)/ & \multicolumn{5}{c}{ Kadar glukosa darah/ Blood glucose level (mg/dL) } \\
\cline { 2 - 6 } Time (minutes) & \multicolumn{1}{c}{ AN } & \multicolumn{1}{c}{ A0 } & A1 & \multicolumn{1}{c}{ A2 } & \multicolumn{1}{c}{ A3 } \\
\hline 0 & $90.40 \pm 6.32^{\mathrm{d}}$ & $148.30 \pm 1.99^{\mathrm{a}}$ & $115.80 \pm 1.48^{\mathrm{b}}$ & $105.10 \pm 1.88^{\mathrm{C}}$ & $91.40 \pm 6.61^{\mathrm{d}}$ \\
30 & $92.40 \pm 4.67^{\mathrm{d}}$ & $120.00 \pm 6.32^{\mathrm{a}}$ & $107.20 \pm 1.15^{\mathrm{c}}$ & $111.10 \pm 0.74^{\mathrm{b}}$ & $106.10 \pm 1.88^{\mathrm{C}}$ \\
60 & $129.20 \pm 5.93^{\mathrm{a}}$ & $132.40 \pm 3.19^{\mathrm{a}}$ & $105.00 \pm 0.79^{\mathrm{b}}$ & $102.80 \pm 1.48^{\mathrm{b}}$ & $103.00 \pm 0.79^{\mathrm{b}}$ \\
120 & $100.90 \pm 11.41^{\mathrm{b}}$ & $137.50 \pm 4.74^{\mathrm{a}}$ & $87.20 \pm 1.48^{\mathrm{b}}$ & $92.90 \pm 5.62^{\mathrm{b}}$ & $85.60 \pm 4.29^{\mathrm{b}}$ \\
\hline
\end{tabular}

Keterangan/Note:

AN: Kontrol negatif (pakan tanpa biskuit)/Negative control (feed without biscuits)

A0: Biskuit tanpa Ulva sp./Biscuits without Ulva sp.

A1: Biskuit Ulva setara dengan Ulva $1 \mathrm{mg} / \mathrm{kg} \mathrm{BB} /$ Ulva biscuits equivalent to $1 \mathrm{mg} / \mathrm{kg}$ body weight

A2: Biskuit Ulva setara dengan Ulva $5 \mathrm{mg} / \mathrm{kg}$ BB/Ulva biscuits equivalent to $5 \mathrm{mg} / \mathrm{kg}$ body weight

A3: Biskuit Ulva setara dengan Ulva $10 \mathrm{mg} / \mathrm{kg}$ BB/Ulva biscuits equivalent to $10 \mathrm{mg} / \mathrm{kg}$ body weight

Huruf superskrip yang berbeda pada baris yang sama menunjukkan hasil yang berbeda nyata pada $p<0.05 /$

The different superscript letter in the same row indicates significantly different $(p<0.05)$

pemberian biskuit Ulva, namun pada batas normal dan tidak berbeda nyata. Hal ini menunjukkan bahwa reseptor yang berikatan masih mampu berinteraksi dengan senyawa kimia yang terkandung dalam Ulva sp. Jika reseptor telah jenuh, maka peningkatan dosis tidak bisa mencapai efek maksimumnya (Pasaribu, Sitorus, \& Bahri, 2012). Menurut Makalalag, Wullur, dan Wiyono (2013), setelah 2 jam, penurunan kadar glukosa darah menunjukkan bahwa telah terjadi eliminasi glukosa pada hewan uji yang diakibatkan oleh pengaruh fisiologis tubuh tikus dengan mensekresikan insulin yang mengubah glukosa menjadi glikogen.

\section{Hematologi}

Profil hematologi menunjukkan terjadi penurunan kadar eritrosit, hematokrit, hemoglobin, leukosit, MCV, $\mathrm{MCH}$, dan limfosit serta peningkatan kadar neutrofil di hari ke-14 pada semua perlakuan, namun nilainya masih dalam batas normal. Secara statistik profil hematologi tikus tidak berbeda nyata pada semua perlakuan pada hari ke-0 dan ke-14. Salah satu parameter hematologi adalah eritrosit, yang berfungsi menyediakan oksigen untuk pembentukan energi dalam proses metabolisme tubuh. Pada penelitian ini, kadar eritrosit turun pada hari ke-14. Hal ini diduga karena perubahan suhu lingkungan. Sebagaimana dilaporkan oleh Wientarsih, Widhyari, dan Aryanti (2013), perubahan suhu lingkungan dan penurunan nafsu makan dapat menurunkan nilai eritrosit. Penurunan nilai eritrosit pada hari ke-14 sejalan dengan penurunan nilai hematokrit. Hematokrit adalah persentase eritrosit di dalam $100 \mathrm{~mL}$ darah (Astawan, Wresdiyati, Arief, \& Suhesti, 2011). Hematokrit pada hari ke-0 (38,10-49,97\%), mengalami penurunan pada hari ke-14 (26,50-32,27\%), tetapi masih dalam batas normal $(37,6-51 \%)$, sebagaimana pada penelitian Pratiwi (2015).

Kadar hemoglobin tidak berbeda nyata $(p>0,05)$ pada semua kelompok perlakuan. Pada hari ke-14 nilai rataan kadar hemoglobin menurun pada semua perlakuan kelompok tikus dan berada di bawah kisaran normal, yaitu 11,4-19,2 g/dL (Astawan et al., 2011). Menurut Pratiwi (2015), penurunan hemoglobin disebabkan oleh kurangnya kadar oksigen yang diikat oleh hemoglobin. Kadar oksigen ini kemungkinan dipengaruhi oleh sirkulasi udara pada lingkungan tempat hidup tikus. Kemungkinan lain penyebab penurunan nilai $\mathrm{Hb}$ karena konsumsi serat pangan yang tinggi. Menurut Yuanita (2005), serat pangan memiliki gugus karboksil yang mampu mengikat $\mathrm{Fe}$ membentuk ikatan kovalen koordinasi, yaitu senyawa pengkelat dengan ikatan kimia yang stabil. Kemungkinan ini dapat menurunkan Fe dalam darah, sehingga menurunkan hemoglobin. Profil hematologi tikus Sprague dawley disajikan pada Tabel 5.

Kadar leukosit tikus sebelum perlakuan 20,97$23,03 \times 10^{3} / \mathrm{mm}^{3}$, setelah perlakuan menurun menjadi $10,30-15,40 \times 10^{3} / \mathrm{mm}^{3}$. Pemberian biskuit dengan dan tanpa Ulva dapat menurunkan jumlah leukosit tikus. Namun, penurunan leukosit masih sedikit di atas batas normal. Menurut Douglas dan Wardrop (2010), jumlah leukosit normal adalah $5-10 \times 10^{3} / \mathrm{mm}^{3}$. Sebelum perlakuan, jumlah leukosit tikus sudah di atas normal. Nilai leukosit tinggi mengindikasikan adanya respons inflamasi akibat infeksi yang disebabkan bakteri maupun virus (Porth, 2011). Pada penelitian ini diduga konsumsi biskuit Ulva mampu mengurangi inflamasi. 
Tabel 5. Hematologi tikus sebelum (hari ke-0) dan sesudah (hari ke-14) perlakuan biskuit Ulva Table 5. Rat hematology before (day-0) and after (day-14) treatments of Ulva biscuit

\begin{tabular}{|c|c|c|c|c|c|}
\hline & \multicolumn{4}{|c|}{ Kelompok/Groups } & \multirow[b]{2}{*}{ A3 } \\
\hline & AN & A0 & A1 & A2 & \\
\hline \multicolumn{6}{|c|}{ Sebelum Perlakuan (hari ke-0)/Before Treatment (Day-0) } \\
\hline $\begin{array}{l}\text { Jumlah eritrosit/Total of } \\
\text { erythrocytes }\left(106 / \mathrm{mm}^{3}\right)\end{array}$ & $5.62 \pm 0.92^{b}$ & $6.50 \pm 0.16^{\mathrm{ab}}$ & $7.06 \pm 0.33^{\mathrm{a}}$ & $6.49 \pm 0.33^{\mathrm{ab}}$ & $7.22 \pm 0.38^{\mathrm{a}}$ \\
\hline Hematokrit/Haematocrit (\%) & $38.10 \pm 8.11^{\mathrm{a}}$ & $46.90 \pm 1.40^{\mathrm{a}}$ & $48.67 \pm 1.46^{\mathrm{a}}$ & $46.50 \pm 2.42^{\mathrm{a}}$ & $49.97 \pm 2.53^{\mathrm{a}}$ \\
\hline Hemoglobin/Haemoglobin ( $\mathrm{g} \%$ ) & $15.27 \pm 3.16^{\mathrm{a}}$ & $16.00 \pm 0.40^{\mathrm{a}}$ & $16.80 \pm 0.69^{\mathrm{a}}$ & $16.00 \pm 0.40^{\mathrm{a}}$ & $17.30 \pm 1.31^{\mathrm{a}}$ \\
\hline $\operatorname{MCV}(\mathrm{fL})$ & $67.67 \pm 5.62^{\mathrm{a}}$ & $72.27 \pm 3.78^{\mathrm{a}}$ & $69.13 \pm 2.97^{\mathrm{a}}$ & $71.67 \pm 0.47^{\mathrm{a}}$ & $69.30 \pm 3.20^{\mathrm{a}}$ \\
\hline $\mathrm{MCH}(\mathrm{pg})$ & $20.80 \pm 3.83^{b}$ & $24.57 \pm 0.40^{\mathrm{a}}$ & $23.73 \pm 0.23^{\mathrm{ab}}$ & $24.67 \pm 1.70^{\mathrm{ab}}$ & $23.87 \pm 0.85^{\mathrm{ab}}$ \\
\hline $\mathrm{MCHC}(\mathrm{g} / \mathrm{dL})$ & $30.73 \pm 3.99^{\mathrm{a}}$ & $34.10 \pm 1.90^{\mathrm{a}}$ & $34.47 \pm 1.14^{\mathrm{a}}$ & $34.43 \pm 2.14^{\mathrm{a}}$ & $34.57 \pm 1.31^{\mathrm{a}}$ \\
\hline $\begin{array}{l}\text { Jumlah leukosit/Total of } \\
\text { leucocytes }\left(10^{3} / \mathrm{mm}^{3}\right)\end{array}$ & $15.73 \pm 1.38^{b}$ & $23.90 \pm 4.01^{\mathrm{a}}$ & $20.97 \pm 2.40^{\mathrm{a}}$ & $20.63 \pm 1.20^{\mathrm{a}}$ & 23.03 \\
\hline \multicolumn{6}{|c|}{ Diferensial darah putih/Leucocytes differential } \\
\hline Limfosit/Lymphocytes (\%) & $80.53 \pm 7.33^{\mathrm{a}}$ & $78.67 \pm 4.67^{\mathrm{a}}$ & $80.97 \pm 2.36^{\mathrm{a}}$ & $83.20 \pm 2.96^{\mathrm{a}}$ & $72.73 \pm 10.82^{\mathrm{a}}$ \\
\hline Monosit/Monocytes (\%) & $1.33 \pm 0.61^{\mathrm{b}}$ & $4.97 \pm 0.75^{\mathrm{ab}}$ & $5.17 \pm 0.91^{\mathrm{a}}$ & $5.03 \pm 1.06^{\mathrm{a}}$ & $6.53 \pm 2.04^{\mathrm{a}}$ \\
\hline Neutrofil/Neutrophils (\%) & $14.17 \pm 2.85^{\mathrm{b}}$ & $15.13 \pm 4.38^{\mathrm{b}}$ & $12.90 \pm 2.49^{a}$ & $10.80 \pm 1.82^{\mathrm{a}}$ & $19.07 \pm 8.16^{\mathrm{a}}$ \\
\hline Eosinofil/Eosinophils (\%) & $1.72 \pm 0.99^{\mathrm{a}}$ & $1.17 \pm 0.35^{\mathrm{a}}$ & $0.90 \pm 0.35^{\mathrm{a}}$ & $0.87 \pm 0.40^{\mathrm{a}}$ & $1.40 \pm 0.69^{\mathrm{a}}$ \\
\hline Basofil/Basophils (\%) & $0.00 \pm 0.00^{\mathrm{a}}$ & $0.07 \pm 0.12^{\mathrm{a}}$ & $0.07 \pm 0.06^{\mathrm{a}}$ & $0.10 \pm 0.17^{\mathrm{a}}$ & $0.27 \pm 0.29^{\mathrm{a}}$ \\
\hline \multicolumn{6}{|c|}{ Setelah Perlakuan (hari ke-14)/After Treatment (Day - 14) } \\
\hline $\begin{array}{l}\text { Jumlah eritrosit/Total of } \\
\text { erythrocytes }\left(10^{6} / \mathrm{mm}^{3}\right)\end{array}$ & $6.57 \pm 0.26^{\mathrm{a}}$ & $5.09 \pm 1.11^{\mathrm{a}}$ & $5.86 \pm 1.44^{\mathrm{a}}$ & $5.81 \pm 1.33^{\mathrm{a}}$ & $5.70 \pm 0.15^{\mathrm{a}}$ \\
\hline Hematokrit/Haematocrit (\%) & $32.27 \pm 1.69^{\mathrm{a}}$ & $26.50 \pm 4.30^{\mathrm{ab}}$ & $28.43 \pm 6.97^{\mathrm{ab}}$ & $30.60 \pm 9.36^{\mathrm{ab}}$ & $27.93 \pm 1.85^{\mathrm{b}}$ \\
\hline Hemoglobin/Haemoglobin ( $\mathrm{g} \%$ ) & $10.27 \pm 0.97^{\mathrm{a}}$ & $8.73 \pm 3.27^{\mathrm{a}}$ & $8.57 \pm 2.58^{\mathrm{a}}$ & $10.30 \pm 5.61^{\mathrm{a}}$ & $8.43 \pm 0.55^{\mathrm{a}}$ \\
\hline $\operatorname{MCV}(\mathrm{fL})$ & $49.20 \pm 1.48^{\mathrm{a}}$ & $52.90 \pm 6.45^{\mathrm{a}}$ & $48.60 \pm 1.21^{\mathrm{a}}$ & $54.17 \pm 6.19^{\mathrm{a}}$ & $49.07 \pm 1.96^{\mathrm{a}}$ \\
\hline $\mathrm{MCH}(\mathrm{pg})$ & $15.57 \pm 0.87^{\mathrm{a}}$ & $16.87 \pm 3.85^{\mathrm{a}}$ & $14.43 \pm 0.95^{\mathrm{a}}$ & $17.10 \pm 4.42^{\mathrm{a}}$ & $14.77 \pm 0.59^{\mathrm{a}}$ \\
\hline $\mathrm{MCHC}(\mathrm{g} / \mathrm{dL})$ & $31.73 \pm 1.93^{\mathrm{a}}$ & $32.13 \pm 6.97^{\mathrm{a}}$ & $29.80 \pm 2.48^{\mathrm{a}}$ & $31.93 \pm 8.96^{\mathrm{a}}$ & $30.13 \pm 0.31^{\mathrm{a}}$ \\
\hline $\begin{array}{l}\text { Jumlah leukosit/Total of } \\
\text { leucocytes }\left(10^{3} / \mathrm{mm}^{3}\right)\end{array}$ & $21.27 \pm 9.12^{\mathrm{a}}$ & $10.95 \pm 2.44^{\mathrm{a}}$ & $15.40 \pm 3.50^{\mathrm{a}}$ & $10.30 \pm 5.16^{\mathrm{a}}$ & $14.83 \pm 3.11^{\mathrm{a}}$ \\
\hline \multicolumn{6}{|c|}{ Diferensial darah putih/Leucocytes differential } \\
\hline Limfosit/Lymphocytes (\%) & $45.37 \pm 15.46^{\mathrm{a}}$ & $36.57 \pm 4.66^{\mathrm{a}}$ & $49.30 \pm 11.36^{\mathrm{a}}$ & $51.80 \pm 19.32^{\mathrm{a}}$ & $48.37 \pm 4.80^{\mathrm{a}}$ \\
\hline Monosit/Monocytes (\%) & $6.27 \pm 1.18^{\mathrm{a}}$ & $7.63 \pm 3.32^{\mathrm{a}}$ & $7.60 \pm 2.09^{\mathrm{a}}$ & $7.33 \pm 2.41^{\mathrm{a}}$ & $8.20 \pm 1.50^{\mathrm{a}}$ \\
\hline Neutrofil/Neutrophils (\%) & $46.57 \pm 16.01^{\mathrm{a}}$ & $41.90 \pm 9.15^{\mathrm{ab}}$ & $40.87 \pm 10.22^{\mathrm{a}}$ & $37.70 \pm 18.00^{\mathrm{a}}$ & $39.60 \pm 6.29^{a}$ \\
\hline Eosinofil/Eosinophils (\%) & $1.40 \pm 0.56^{\mathrm{b}}$ & $0.73 \pm 0.67^{b}$ & $1.70 \pm 0.79^{\mathrm{a}}$ & $2.50 \pm 0.60^{\mathrm{a}}$ & $3.20 \pm 0.61^{a}$ \\
\hline Basofil/Basophils (\%) & $0.40 \pm 0.35^{\mathrm{a}}$ & $0.27 \pm 0.06^{\mathrm{a}}$ & $0.53 \pm 0.35^{\mathrm{a}}$ & $0.67 \pm 0.21^{\mathrm{a}}$ & $0.63 \pm 0.38^{\mathrm{a}}$ \\
\hline
\end{tabular}

Keterangan/Note:

AN: Kontrol negatif (pakan tanpa biskuit)/Negative control (feed without biscuits)

A0: Biskuit tanpa Ulva sp./Biscuits without Ulva sp.

A1: Biskuit Ulva setara dengan Ulva $1 \mathrm{mg} / \mathrm{kg} \mathrm{BB} /$ Ulva biscuits equivalent to $1 \mathrm{mg} / \mathrm{kg}$ body weight

A2: Biskuit Ulva setara dengan Ulva $5 \mathrm{mg} / \mathrm{kg}$ BB/Ulva biscuits equivalent to $5 \mathrm{mg} / \mathrm{kg}$ body weight

A3: Biskuit Ulva setara dengan Ulva $10 \mathrm{mg} / \mathrm{kg}$ BB/Ulva biscuits equivalent to $10 \mathrm{mg} / \mathrm{kg}$ body weight

Huruf superskrip yang berbeda pada kolom yang sama menunjukkan hasil yang berbeda nyata pada $p<0.05 /$

The different superscript letter in the same column indicates significantly different $(p<0.05)$ 


\section{Biokimia Klinis Darah}

Pengukuran kadar SGPT dan SGOT dimaksudkan untuk melihat pengaruh perlakuan terhadap kerusakan fungsi hati. Menurut Baroni et al. (2016), ketika sel hati mengalami kerusakan karena hiperglikemik, enzim SGPT dan SGOT akan keluar dan masuk ke dalam sirkulasi darah. Dengan demikian peningkatan kadar enzim tersebut dalam darah mengindikasikan terjadi kerusakan sel hati. Menurut Yuneldi, Saraswati, dan Yuniwarti (2018), kandungan normal SGPT pada tikus adalah 17,5-30,2 U/L, sedangkan menurut Giknis dan Clifford (2008) sebesar 18-45 U/ L. Hasil penelitian lain menyatakan kadar normal SGOT tikus Wistar jantan (Rattus norvegicus) 126,5 U/L (Qodriyati, Sulistyani, \& Yuwono, 2016). Hasil analisis statistik menunjukkan biokimia darah tikus sebelum (hari ke-0) dan setelah perlakuan biskuit Ulva (hari ke-14) tidak berbeda nyata di antara perlakuan, baik pada SGOT, SGPT, ureum, dan kreatinin. Nilai SGOT tikus jantan pada penelitian ini sudah tinggi sejak sebelum perlakuan. Menurut Wahdaningsih, Setyowati dan Wahyuono (2011), kadar SGOT yang tinggi pada hewan coba kemungkinan disebabkan oleh faktor pakan, lingkungan, dan stres. Tingginya nilai SGOT tersebut sangat kecil kemungkinan disebabkan oleh pemberian biskuit Ulva. Menurut Tamat, Wikanta, \& Maulina (2007) rumput laut Ulva sp. tidak mempunyai sifat toksik sampai dengan pemberian $250 \mu \mathrm{g} / \mathrm{mL}$ pada Artemia salina. Hal yang sama juga dinyatakan oleh Lekshmi, Rauf, dan Muraleedhara Kurup (2019) bahwa hasil uji toksisitas Ulva fasciata sampai dosis $50 \mathrm{mg} / \mathrm{kg}$ BB pada tikus tidak bersifat toksik.

Kadar ureum dalam darah tikus setelah hari ke-14 berkisar 17,70-28,21 mg/dL. Menurut Levine dan Saltzman (1999), kadar normal ureum dalam darah berkisar $12-42 \mathrm{mg} / \mathrm{dL}$. Setelah perlakuan sampai hari ke-14, terjadi peningkatan kadar ureum baik untuk perlakuan pemberian biskuit Ulva maupun tanpa perlakuan, namun peningkatan ureum tersebut masih dalam kategori normal.

Kreatinin adalah produk akhir metabolisme kreatin fosfat berupa senyawa nitrogen non protein. Metabolisme kreatin terjadi dengan bahan baku asam amino glisin, arginin, dan metionin (Cole, 1986). Hasil pengamatan menunjukkan kadar kreatinin darah tikus setelah hari ke-14 berkisar 0,29-0,92 mg/dL. Menurut Baron et al. (1974), kadar normal kreatinin dalam darah

Tabel 6. Biokimia klinis darah tikus sebelum (hari ke-0) dan sesudah (hari ke-14) perlakuan biskuit Ulva Table 6. Clinical biochemistry performance of rat blood before (day-0) and after (day-14) treatment of Ulva biscuits

\begin{tabular}{|c|c|c|c|c|c|}
\hline & \multicolumn{5}{|c|}{ Kelompok/Groups } \\
\hline & AN & A0 & A1 & A2 & A3 \\
\hline \multicolumn{6}{|c|}{ 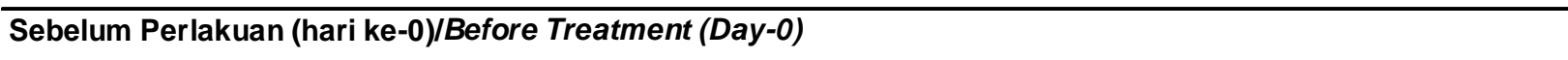 } \\
\hline SGPT (U/L) & $35.69 \pm 3.24^{\mathrm{a}}$ & $33.30 \pm 2.55^{\mathrm{a}}$ & $38.10 \pm 6.65^{\mathrm{a}}$ & $32.40 \pm 1.05^{\mathrm{a}}$ & $34.57 \pm 1.31^{\mathrm{a}}$ \\
\hline SGOT (U/L) & $134.14 \pm 11.58^{\mathrm{a}}$ & $149.47 \pm 6.14^{\mathrm{a}}$ & $120.17 \pm 32.69^{a}$ & $128.70 \pm 48.93^{\mathrm{a}}$ & $121.68 \pm 15.51^{\mathrm{a}}$ \\
\hline Ureum/Urea (mg/dL) & $14.19 \pm 7.0^{\mathrm{a}}$ & $13.29 \pm 4.27^{\mathrm{a}}$ & $13.01 \pm 2.68^{\mathrm{a}}$ & $22.27 \pm 4.36^{\mathrm{a}}$ & $14.35 \pm 5.15^{\mathrm{a}}$ \\
\hline Kreatinin/Creatinine (mg/dL) & $0.14 \pm 0.03^{\mathrm{a}}$ & $0.44 \pm 0.07^{\mathrm{a}}$ & $0.30 \pm 0.49^{\mathrm{a}}$ & $0.48 \pm 0.27^{\mathrm{a}}$ & $0.23 \pm 0.16^{\mathrm{a}}$ \\
\hline \multicolumn{6}{|c|}{ Setelah perlakuan (hari ke-14)/ After Treatment (Day-14) } \\
\hline SGPT (U/L) & $37.06 \pm 7.35^{\mathrm{a}}$ & $33.46 \pm 21.12^{\mathrm{a}}$ & $31.58 \pm 8.27^{\mathrm{a}}$ & $24.76 \pm 3.29^{\mathrm{a}}$ & $33.43 \pm 18.02^{\mathrm{a}}$ \\
\hline SGOT (U/L) & $139.87 \pm 35.63^{\mathrm{a}}$ & $139.88 \pm 10.50^{\mathrm{a}}$ & $138.61 \pm 19.91^{\mathrm{a}}$ & $107.36 \pm 9.67^{a}$ & $127.38 \pm 7.86^{\mathrm{a}}$ \\
\hline Ureum/Urea (mg/dL) & $22.91 \pm 15.31^{\mathrm{a}}$ & $27.63 \pm 10.17^{\mathrm{a}}$ & $25.36 \pm 16.43^{\mathrm{a}}$ & $28.21 \pm 8.10^{\mathrm{a}}$ & $17.70 \pm 5.70^{\mathrm{a}}$ \\
\hline Kreatinin/Creatinine $(\mathrm{mg} / \mathrm{dL})$ & $0.29 \pm 0.25^{a}$ & $0.70 \pm 0.33^{\mathrm{a}}$ & $0.69 \pm 0.50^{\mathrm{a}}$ & $0.92 \pm 0.53^{\mathrm{a}}$ & $0.62 \pm 0.37^{\mathrm{a}}$ \\
\hline
\end{tabular}

Keterangan/Note:

AN: Kontrol negatif (pakan tanpa biskuit)/Negative control (feed without biscuits)

A0: Biskuit tanpa Ulva sp./Biscuits without Ulva sp.

A1: Biskuit Ulva setara dengan Ulva $1 \mathrm{mg} / \mathrm{kg} \mathrm{BB} /$ Ulva biscuits equivalent to $1 \mathrm{mg} / \mathrm{kg}$ body weight

A2: Biskuit Ulva setara dengan Ulva $5 \mathrm{mg} / \mathrm{kg} \mathrm{BB} / \mathrm{Ulva}$ biscuits equivalent to $5 \mathrm{mg} / \mathrm{kg}$ body weight

A3: Biskuit Ulva setara dengan Ulva $10 \mathrm{mg} / \mathrm{kg} \mathrm{BB} /$ Ulva biscuits equivalent to $10 \mathrm{mg} / \mathrm{kg}$ body weight

Huruf superskrip yang berbeda pada kolom yang sama menunjukkan hasil yang berbeda nyata pada $p<0.05 /$

The different superscript letter in the same column indicates significantly different $(p<0.05)$ 
adalah 0,40-1,37 mg/dL. Hasil penelitian lain dari Dewi, Hairrudin, dan Normasari (2016) menyebutkan bahwa kadar kreatinin serum normal tikus wistar 0,578-1,128 $\mathrm{mg} / \mathrm{dL}$. Hasil penelitian ini menunjukkan kadar kreatinin darah tikus percobaan dari semua perlakuan masih dalam kategori normal. Hal ini menunjukkan bahwa pemberian biskuit Ulva sampai konsentrasi $1 \%$ atau setara dengan dosis Ulva sp. $10 \mathrm{mg} / \mathrm{kg} \mathrm{BB}$ selama 14 hari tidak memberikan pengaruh terhadap kadar SGOT, SGPT, ureum, dan kreatinin. Walaupun nilai kreatinin tikus masih normal, namun terjadi peningkatan kreatinin setelah hari ke-14. Jika konsentrasi biskuit Ulva diperbesar kemungkinan dapat meningkatkan nilai kreatinin yang dapat menyebabkan gejala penurunan fungsi ginjal. Hal ini sebagaimana dilaporkan Kurniawaty et al. (2020) bahwa peningkatan nilai kreatinin merupakan salah satu gejala penurunan fungsi ginjal.

\section{KESIMPULAN}

Pemberian biskuit Ulva yang mengandung tepung Ulva sp. $0,1 \%$ atau setara dengan dosis Ulva sp. 1 $\mathrm{mg} / \mathrm{kg}$ BB efektif menurunkan kadar glukosa darah tikus dan berbeda nyata dengan kontrol negatif dan biskuit tanpa Ulva. Meskipun pemberian biskuit Ulva juga menurunkan nilai hematokrit dan hemoglobin pada darah tikus, namun kadarnya tidak berbeda nyata di antara semua perlakuan. Biskuit dengan konsentrasi Ulva sp. sampai dengan 1\% (setara dengan dosis U/va sp. $10 \mathrm{mg} / \mathrm{kg} \mathrm{BB}$ ) yang diberikan pada tikus selama 14 hari tidak mempengaruhi nilai SGOT, SGPT, ureum, dan kreatinin pada darah tikus.

\section{DAFTAR PUSTAKA}

American Diabetes Association (ADA). (2004). Gestational Diabetes Mellitus. Diabetes Care, 27, S88-S90.

Alves, A., Sousa, R. A., \& Reis, R. L. (2013). A practical perspective on ulvan extracted from green algae. Journal of Applied Phycology, 25(2), 407-424. doi: 10.1007/s10811-012-9875-4.

Arif, A., Budiyanto, A., \& Hoerudin, H. (2013). Nilai indeks glikemik produk pangan dan faktor-faktor yang memengaruhinya. Jurnal Penelitian dan Pengembangan Pertanian, 32(3), 30926. doi: 10.21082/jp3.v32n3.2013.p91-99.

AOAC. (2006). Official Methods of Analysis, 18th ed. Association of Official Analytical Chemists, Arlington, VA, USA.

Astawan, M., Wresdiyati, T., Arief, I. I., \& Suhesti, E. (2011). Gambaran hematologi tikus putih (Rattus norvegicus) yang diinfeksi Escherichia coli enteropatogenik dan diberikan probiotik. Media Peternakan, 34(1), 7-13. doi: 10.5398/ medpet.2011.34.1.7.
Badan Standardisasi Nasional (BSN). (2006a). Pengujian Kadar Air pada Produk Perikanan. SNI No. 01-2354.2.2006. Badan Standardisasi Nasional

Badan Standardisasi Nasional (BSN). (2006b). Pengujian Kadar Lemak pada Produk Perikanan. SNI No. 01-2354.3.2006. Badan Standardisasi Nasional.

Badan Standardisasi Nasional (BSN). (2006c). Pengujian Kadar Protein pada Produk Perikanan. SNI No. 01-2354.4.2006. Badan Standardisasi Nasional.

Badan Standardisasi Nasional (BSN). (2010). Pengujian Kadar Abu pada Produk Perikanan. SNI No. 01 2354.1-2010. Badan Standardisasi Nasional.

Baron, D. N., Broughton, P. M. G., Cohen, M., Lansley, T. S., Lewis, S. M., \& Shinton, N. K. (1974). The use of SI units in reporting results obtained in hospital laboratories. Annals of Clinical Biochemistry, 11(5), 194-202.doi: 10.1177/000456327401100154.

Baroni, S., Rocha, B. A., Oliveira de Melo, J., Comar, J. F., Caparroz-Assef, S. M., \& Bersani-Amado, C. A. (2016). Hydroethanolic extract of Smallanthus sonchifolius leaves improves hyperglycemia of streptozotocin induced neonatal diabetic rats. Asian Pacific Journal of Tropical Medicine, 9(5), 432-436. doi: 10.1016/ j.apjtm.2016.03.033

Badan Pengawasan Obat dan Makanan (BPOM). (2014). PerKaBPOM No. 7 tahun 2014 tentang Pedoman uji toksisitas non klinik secara In vivo. BPOM: Jakarta

Cole, E. H. (1986). Veterinary Clinical Pathology. 4 th Ed.WB. Saunders. Philadelphia, USA.

Dewi, P. R. P., Hairrudin, \& Normasari, R. (2016). Pengaruh stres fisik terhadap kadar kreatinin serum Tikus Wistar Jantan (Rattus norvegicus). Jurnal Pustaka Kesehatan, 4 (2), 218-221.

Douglas, J. W. \& Wardrop, K. J. (2010). Schalm's Veterinary Hematology. 6th ed. Wiley-Blackwell. p852-887.

Dwiyitno. (2011). Rumput laut sebagai sumber serat pangan potensial. Squalen Bulletin of Marine and Fisheries Postharvest and Biotechnology, 6(1), 9-17.

Ganong, W. F. (1999). Fisiologi Kedokteran, Edisi ke14. Jonatan Oswari. Jakarta: Penerbit Buku Kedokteran EGC.

Giknis, M. L. A. \& Clifford, C.B. (2008). Clinical Laboratory Parameters For Crl:WI(Han) Rats. Charles River Laboratories.

Kidgell, J. T., Magnusson, M., Nys, D., \& Glasson, C. R. K. (2019). Ulvan: a systematic review of extraction, composition and function. Review article, Algal Research, 39, 1-20. doi: 10.1016/j.algal.2019. 101422

Kondoy, S., Wullur, A., \& Bodhi, W. (2013). Potensi ekstrak etanol daun kayu manis (Cinnamomum) dari tikus putih jantan (Rattus norvegicus) yang di induksi sukrosa. Pharmacon, 2(03), 96-99

Kusharto, C. M. (2007). Serat makanan dan perannya bagi kesehatan. Jurnal Gizi dan Pangan, 1(2), 4554. doi: 10.25182/jgp.2006.1.2.45-54

Kurniawaty, E, Lumban Gaol, F. F, Kurniati, I, Andriani, S, Rahmanisa, S, dan Andriani, S. (2020). Systematic reviews in pharmacy, 11(12), 407-408. 
Lekshmi, V. S., Rauf, A. A., \& Muraleedhara Kurup, G. (2019). Toxicological evaluation of bioactive sulfated polysaccharides from the edible marine algae Padina tetrastromatica and Ulva fasciata in Sprague-Dawley rats. Journal of Biologically Active Products from Nature, 9(2), 79-96.

Levine, S., \& Saltzman, A. (1999). Effects of coprophagy on serum urea and the weight of the gastrointestinal tract of fed or fasted rats. Laboratory Animals, 33(3), 265-268.doi: 10.1258/002367799780578093

Makalalag, I. W., Wullur, A., \& Wiyono, W. (2013). Uji ekstrak daun Binahong (Anredera cordifolia Steen) terhadap kadar gula darah pada tikus putih jantan galur Wistar (Rattus norvegicus) yang diinduksi sukrosa. Pharmacon, 2(1), 28-35.

Mohapatra, L., Bhattamishra, S. K., Panigrahy, R., \& Parida, S. (2016). Antidiabetic effect of Sargassum wightii and Ulva fasciata in high fat diet and multi low dose streptozotocin induced type 2 diabetic mice. UK Journal of Pharmaceutical and Biosciences, 4(2), 13-23. doi: 10.20510/ukjpb/4/i2/97081

Pasaribu, F., Sitorus, P., \& Bahri, S. (2012). Uji ekstrak etanol kulit buah manggis (Garcinia mangostana L.) terhadap penurunan kadar glukosa darah. Journal of Pharmaceutics and Pharmacology, 1(1), 1-8.

Pereira, M. S., Mulloy, B., \& Mourão, P. A. S. (1999). Structure and anticoagulant activity of sulfated fucans. Comparison between the regular, repetitive, and linear fucans from echinoderms with the more heterogeneous and branched polymers from brown algae. Journal of Biological Chemistry, 274(12), 76567667. doi: 10.1074/jbc.274.12.7656

Porth, C. M. (2011). Inflammation, the inflammatory response, and fever: white blood cell response. Essentials of Pathophysiology: Concepts of Altered Health States. 3 rd ed. Philadelphia: Wolters Klower Health/Lippincott Williams \& Wilkins.

Pratiwi, N. A. (2015). Gambaran hemoglobin pada perokok di kampong adat Cireundu. Diakses : http:/ /repository.poltekkesbdg .info/items/show/549 d, tanggal 12 Januari 2019

Qodriyati, N. L. Y., Sulistyani, E., \& Yuwono, B. (2016). Kadar serum Glutamic Oxaloacetic Transaminase (SGOT) pada Tikus Wistar (Rattus norvegicus) jantan yang dipapar stresor rasa sakit electrical foot shock selama 28 Hari. Jurnal Pustaka Kesehatan, 4(1), 73-76.

Rahayu, L., Yantih, N., \& Supomo, Y. (2018). Analisis SGPT dan SGOT pada tikus yang diinduksi isoniazid untuk penentuan dosis dan karakteristik hepatoprotektif air buah nanas (Ananas comosus L. Merr) mentah. Jurnal IImu Kefarmasian Indonesia, 16(1), 100-106.

Robic, A., Gaillard, C., Sassi, J. F., Leral, Y., \& Lahaye, M. (2009). Ultrastructure of Ulvan: A polysaccharide from green seaweeds. Biopolymers, 91(8), 652-664. doi: 10.1002/bip.21195

Rokhmah, F. D, Handayani, D, \& Al-Rasyid, H. (2015). Korelasi lingkar pinggang dan rasio lingkar pinggang-panggul terhadap kadar glukosa plasma menggunakan tes toleransi glukosa oral. Jurnal Gizi Klinik Indonesia, 12(1), 28-35.

Setyowati, W. T. \& Nisa, F. C. (2014). Formulasi biskuit tinggi serat (kajian proporsi bekatul jagung: tepung terigu dan penambahan baking powder) high-fiber biscuit formulations (study of the proportions of corn bran: wheat flour and addition of baking powder). Jurnal Pangan dan Agroindustri, 2(3), 224-231.

Tama, C., Dewi E. N., \& Ibrahim. (2012). Pengaruh pemberian ekstrak Gracilaria verrucosa terhadap kadar glukosa darah tikus putih (Rattus norvegicus). Jurnal Saintek Perikanan, 8(1), 1-6.

Tamat, S. R., Wikanta, T., \& Maulina, L. S. (2007). Aktivitas antioksidan dan toksisitas senyawa bioaktif dari ekstrak rumput laut hijau Ulva reticulata Forsskal. Jurnal IImu Kefarmasian Indonesia, 5(1), 31-36.

Tara, E. \& Soetrisno, E. (2002). Buku pintar terapi diabetes mellitus. Taramedia dan Restu Agung: Jakarta. 124p.

Thunyawanichnondh, J., Suebsiri, N., Leartamonchaikul, S., Pimolsri, W., Jittanit, W., \& Charoensiddhi, S. (2020). Potential of green seaweed Ulva rigida in Thailand for healthy snacks. Journal of Fisheries and Environment, 44(1), 29-39.

Togubu, S., Momuat, L. I., Paendong, J. E., \& Salma, N. (2013). Aktivitas antihiperglikemik dari ekstrak etanol dan heksana tumbuhan suruhan (Peperomia pellucida [L.] Kunth) pada Tikus Wistar (Rattus norvegicus L.) yang Hiperglikemik. Jurnal MIPA, 2(2), 109. doi: 10.35799/jm.2.2.2013.2999

Wahdaningsih, S., Setyowati, E. P., \& Wahyuono, S. (2011). Aktivitas penangkap radikal bebas dari batang pakis (Alsophila glauca J. Sm). Majalah Obat Tradisional. 16(3),156-60.

Wientarsih, I., Widhyari, S. D., \& Aryanti, T. (2013). Kombinasi imbuhan herbal kunyit dan Zink dalam pakan sebagai alternatif pengobatan Kolibasilosis pada ayam pedaging. Jurnal Veteriner, 14(3), 327-334.

Yaich, H., Garna, H., Bchir, B., Besbes, S., Paquot, M., Richel, A., ... \& Attia, H. (2015). Chemical composition and functional properties of dietary fibre extracted by Englyst and Prosky methods from the alga Ulva lactuca collected in Tunisia. Algal Research, 9, 6573. doi: 10.1016/j.algal.2015.02.017

Yuneldi, R. F., Saraswati, T. R., \& Yuniwarti, E. Y. (2018). Profile of SGPT and SGOT on Male Rats (Rattus norvegicus) Hyperglycemic After Giving Insulin Leaf Extract (Tithonia diversifolia). Biosaintifika, 10(3), 519-525. doi : 10.15294/biosaintifika.v10i3. 5516

Yusrani, N. L. A., Darmayanti, L. P. T., \& Yusa, N. (2015). Efek hipoglikemik diet rumput laut Gracilaria dan Caulerpa pada tikus diabetes induksi alloxan. Seminar Nasional Sains dan Teknologi (Senastek), 246-301.

Yuanita, L. (2005). Pengaruh diet tinggi serat pangan terhadap absorpsi Fe dan efisiensi regenerasi $\mathrm{Hb}$ Rattus norvegicus. Journal of Biological Researches, 11(1), 5-11. doi: 10.23869/ bphjbr.11.1.20052 